Zabytkoznawstwo i Konserwatorstwo XXXIX, Toruń 2010

Katarzyna Wantuch-Jarkiewicz

Uniwersytet Mikołaja Kopernika w Toruniu

\title{
Rama do obrazu w służbie kształtowania wnętrza
}

$A_{\text {stawienia bliskich. Ramy w czasach przeprowadzek spełniały funkcję }}^{\text {tmosfere domu tworza meble, a dopełniaja obrazy kultowe czy przed- }}$ ochronną dla obrazów o nieraz dużej, obok artystycznej, wartości materialnej. Obrazy wraz z ramami zawsze miały zatem duży udział w kształtowaniu wnętrza, bez względu na to, czy jego charakter wynikał z przypadkowego zestawienia przedmiotów pochodzących z różnych epok, czy też z przemyślanego projektowania elementów całego pomieszczenia.

W okresie średniowiecza rama była związana z obrazem w sposób „organiczny" ${ }^{1}$ - odzwierciedleniem tej tendencji były ołtarze szafowe we wnętrzu kościelnym czy małe dewocyjne warianty tej formy we wnętrzach świeckich. Wraz ze wzrostem zainteresowania człowiekiem do wnętrz na stałe zawitał obraz oderwany nie tylko od tematyki sakralnej, ale również od ramy architektonicznej, tak mocno związanej uprzednio zarówno z obrazem, jak i z architektura. Dalsza ewolucja ramy przebiegała więc dwutorowo. Z jednej strony wiązała się dalej z obrazem, a z drugiej - z wnętrzem, najbliższym otoczeniem. Nieodłącznym elementem każdego wnętrza mieszczańskiego stał się portret członka rodziny, a sakralnego - zdobywające coraz większą popularność dewocyjne ujęcia Madonny z Dzieciątkiem czy popularne już w średniowieczu przedstawienia Świętej Rodziny, Narodzenia Pańskiego, Ukrzyżowania. Te ostatnie pojawiały się we wczesnym renesansie również

1 Związek ten dobrze oddaje ang. słowo engaged. 
we wnętrzach świeckich², swoją wymową wspierając posługę wyznawców Kościoła katolickiego. Właśnie w okresie odrodzenia nastąpiło przewartościowanie roli artysty i dzieła; sztuki wyzwolone objęły także malarstwo, a w ich cieniu pozostała rama i tak jest do dziś. Rama, jako wytwór rzemiosła artystycznego, jest bliższa sztuce użytkowej. Często ignorują ją sami twórcy, czego szczytową formą jest „antyrama” - czyli brak ramy.

Nieodłącznym elementem powstawania układów kulturowych są przemiany społeczno-polityczne zachodzące lokalnie oraz globalnie. W okresie nowożytnym klasy społeczne, tworząc się, kształtowały upodobania sfer wyższych, czego przejawem były zaczątki pierwszych kolekcji, co w dalszym etapie zaowocowało powstaniem gabinetów, a później muzeów. Francis Bacon ${ }^{3}$ w wydanym w 1594 roku Gesta Grayorum wymienił najistotniejsze jego zdaniem elementy składające się na „aparat” naukowy, niezbędny dla wykształconego gentlemana. W myśl jego teorii niezbędne było poszerzenie wiedzy poprzez skompletowanie najznakomitszej biblioteki, założenie i pielęgnowanie przestronnego ogrodu z bogatymi okazami fauny i flory, stworzenie obszernego gabinetu, w którym znajdą sie „,wszystkie rzeczy rzadkie wykonane przez człowieka w tworzywie, metodami właściwymi dla sztuk pięknych lub przy pomocy maszyn, wytworzone przez przypadek "naturalia» czy przez człowieka "artificalia"” " (il. 1). W dalszej kolejności potrzebne jest jeszcze jedno pomieszczenie zarezerwowane dla instrumentów, pieców i naczyń.

Kolekcje te z czasem przerodziły się w „Kunstkammery”, z których należy wymienić te najsławniejsze: Franciszka I Mediciego we Florencji, elektora Fryderyka Augusta w Dreźnie, księcia Albrechta V i jego żony Anny w Monachium, Rudolfa II w Pradze, Joachima Friedricha w Berlinie, Piotra I w Petersburgu. Zbieraniem obrazów i innych przedmiotów artystycznych zaj-

2 Na przykład XVI-wieczne wspaniałe freski w ratuszu w Świdnicy. Zachowały się tam sceny Sądu Ostatecznego, Ukrzyżowania i Sądu nad Jawnogrzesznicą. Z przekazów wiemy, że były tam także obrazy sztalugowe.

3 A. Rotermund, Obraz i rama we wnetrzach europejskich rezydencji nowożytnych, [w:] Materiały Muzeum Wnętrz Zabytkowych w Pszczynie, t. 6, pod red. J. Ziembińskiego, Pszczyna 1990, s. 13-14.

4 W wiekach XVII i XVIII miejsca te zwano także „closet of rarities”, „Wunderkammer”, „cabinet of curiosities”. Ibidem, s. 14. 
mowali się także magnaci, kler oraz artyści. Na przykład Rubens posiadał sporą kolekcję obrazów, którą szczególowo opisał w inwentarzu, podając także atrybucje. Niektórzy kolekcjonerzy nie ustalali autorstwa obrazów czy rzeźb i układali je podług motywu na nich przedstawionego, a nie autora czy szkoły $^{5}$ (il. 2).

Gabinety miały służyć dwóm nierozłącznym celom: podtrzymywaniu tradycji i jej wzbogacaniu. Im dalej od źródeł kulturowych, tym większy deficyt dzieł oryginalnych i tym większe znaczenie egzemplarza zastępczego kopii. Stała się ona jedynym sposobem na zaspokojenie potrzeb kulturalnych nowych klas społecznych. Poświęcanie uwagi sztuce w wiekach XVII i XVIII było o wiele bardziej powszechne niż w wiekach XV i XVI. Interesowało się nią mieszczaństwo, a zwłaszcza inteligencja ${ }^{6}$.

W epoce oświecenia sztuka przestała byćdomeną elit kościelnychi świeckich, a stała się udziałem wielu. Zakładane w pałacach gabinety, galerie - zalążki formuly muzealnej, tracą swą ekskluzywność, otwierają się dla curieux i turystów. Zainteresowanie zbiorami, a zwłaszcza powstanie nadwornych szkół artystycznych, doprowadziło do stopniowego wydzielenia się przestrzeni muzealnej, jej oddzielenia się od dworu i uzyskania przez nią znacznej autonomii. Tak powstała specjalna architektura muzealna, np. w Dreźnie, Poczdamie, Wiedniu czy innych miastach Europy. Sama funkcja gabinetów ewoluuje wraz z prądami społeczno-kulturowymi: zamiast reprezentacyjnej pojawiają się funkcje dydaktyczne i oświatowe. Układ zbiorów także przechodzi różne etapy: od prostego podziału na „naturalia” i „artificalia”, przez podsumowującą poszukiwania siedmiogatunkową koncepcję C. F. Neickla ${ }^{7}$,

5 Z. Zaremba-Filipczak, Picturing Art in Antwerp, Princeton 1968, s. 66, 75.

6 Wiele kolekcji powstawało także w zakonach. Niektóre inwentarze wzmiankują również o ramach do obrazów: „Obraz P. Jezusa Ukrzyżowanego w ramach bursztynowych [...] Obrazów różnych w złocistych ramkach”, J. Poklewski, Inwentarz misji jezuickiej w Liczkowicach z 1717 r., „Acta Universitatis Nicolai Copernici, Zabytkoznawstwo i Konserwatorstwo", t. 7, Toruń 1979, s. 92.

7 C. F. Neickel, 1727 r., Kunstkammer, Achatzkammer, Galeria, Antiquitätenkammer, Raritätenkammer (czyli Wunderkammer), Studio-Muzeum, Naturalienkabinett; A. Rotermund, op. cit., s. 16; Z. Waźbiński, Muzeum i zbiory artystyczne epoki nowożytnej, cz. 2: Wiek XVII i XVIII, Uniwersytet Mikołaja Kopernika, „Skrypty i Teksty Pomocnicze”, Torun 1988, s. 112. 
aż do przekształcenia ekspozycji muzealnej w układ chronologiczny, obrazujący dzieje sztuki i uporządkowany według szkół.

Rozciagnnięcie kolekcjonerstwa również na stan mieszczański doprowadziło do rozwoju rzemiosła obsługującego ten ruch. Oprawianiem obrazów zajmowali się ebeniści, snycerze, stolarze i wytwórcy mebli, a ich projektowaniem głównie architekci (czasem rolę tę przejmowali właściciele kolekcji bądź brali czynny udział w procesie projektowania). Rama związała się bardziej z dekoracją wnętrza niż z obrazem, z którym niegdyś była tak ściśle skorelowana ${ }^{8}$. Jej forma zależała od właściwego obsadzenia obrazu w kompozycji wnętrza złożonego z podziałów ścian i sufitów, kolorystyki ścian i współgrania dekoracji z umieszczonymi we wnętrzu meblami (il. 3). Wartość artystyczna samego malarstwa spadła na dalszy plan. Z odwołująca się do antyku klasycystyczną ramą jest związane nowe spojrzenie na sztukę. Natomiast nowa estetyka oświecenia zwalcza wykorzystywanie sztuki do jakichkolwiek celów. Jeżeli artyście lub widzowi chodziło o oddzielenie „wewnątrz-estetycznej” sfery postrzegania, to rama miała właśnie oddzielać tę sferę od świata codziennego. To rozgraniczenie „na zewnątrz” dotyczyło obrazów we wszystkich epokach. Nie można było więc, tak jak w czasach baroku, połączyć formy wyrazu ramy z konkretną, określoną koncepcją wymowy współczesnego jej obrazu o podobnym stylu. Przez to rama stała się częścią wystroju wnętrz, przedmiotem, który przez swoją postać wywołuje jedynie ogólne estetyczne nastawienie, podobnie jak inne elementy wnętrz (il. 4).

Posiadanie zbioru dzieł sztuki stawało się nieodzownym atrybutem pozycji społecznej, świadectwem dobrego smaku.

Przekonanie takie odzwierciedla wygląd ówczesnych galerii, znanych nam z malarstwa. Są w nich przedstawione ściany wypełnione obrazami w ciasnym układzie (jeden obok drugiego i nad innym), co miało podkreślać nieograniczone możliwości zdobywania dzieł sztuki przez zamożnego kolekcjonera. W gabinecie obraz był jedynym elementem wyposażenia i nie musiał konkurować z meblami znajdującymi się we wnętrzach. Ale i tu nie było miejsca na indywidualne ujęcie ramy; sprowadzono ją do form najprostszych

$8 \quad$ A. Rotermund, op. cit., s. 17. 
profili, oddzielających jeden obraz od drugiego. Nie tylko rama nie miała znaczenia w układzie dekoracji XVIII-wiecznych gabinetów. Szkoła i chronologia przedstawionego w nich malarstwa nie odgrywały żadnej roli. W innych pomieszczeniach obowiązywały zasady sugerowane przez ówczesnych kolekcjonerów i krytyków sztuki. Odnosiły się one do tematyki obrazów zawieszanych np. w gabinetach paradnych, sypialniach, na klatkach schodowych lub do sposobu ustawiania ich względem światła i patrzacego ${ }^{9}$.

Praktyką nierzadką było także zmienianie formatu i kompozycji obrazu w celu dostosowania jego wielkości do projektu wnętrza (wiedeńska kolekcja Karola VI, kolekcja Wittelsbachów z zamku Schleissheim) ${ }^{10}$.

Kiedy ramy przestały być silnie związane z innymi obrazami (gabinety - ramy proste) czy architekturą (ramy architektoniczne), stały się bardziej ozdobne - ornamentalne. W XVIII wieku przestrzenie między obrazami $\mathrm{w}$ gabinetach powiększały się. $\mathrm{W}$ innych pomieszczeniach ramy stopniowo uwalniały się od architektury. Nastąpił szybki rozkwit różnorodnych form ornamentalnych, wywodzących się jednakże z architektury. Szczególne miejsce zajmują w tym rozwoju francuskie ramy pierwszej połowy XVIII wieku. W drugiej połowie tego stulecia wytworzył się zwyczaj wieszania obrazów rzędami na ciemnoczerwonych lub zielonych tłach, który stał się popularny w całej Europie (galeria w Corsham Court zbudowana w 1760 roku, paryski salon Madame Geoffrin, berlińska galeria Daniela Chodowieckiego, warszawska galeria Stanisława Augusta na Zamku Królewskim) ${ }^{11}$.

Jak już wspomniano, na kształt i dekorację ramy wpływały w XVIII wieku (bardziej niż w wiekach wcześniejszych) gust i opinia właściciela kolekcji. Przykłady takiego postępowania można odnaleźć w drezdeńskiej galerii Augusta II i Augusta III oraz kolekcji Stanisława Augusta Poniatowskiego. Unifikacja ramy dotyczy zbiorów należących do jednego właściciela bądź jest przypisywana danemu wnętrzu. Miała ona na celu z jednej strony oznaczenie przynależności do jednej kolekcji, a z drugiej - wydobycie funkcji dydaktycznej, realizującej zadania stawiane przez rodzącą się pod koniec XVIII wieku

9 Ibidem, s. 26-27.

10 Ibidem, s. 29.

11 Ibidem, s. 31-32. 
dyscyplinę naukową - historię sztuki ${ }^{12}$. Dopiero w XIX wieku, wraz z pojawieniem się nowego odbiorcy - klasy średniej, i wzrastającą liczbą kolekcji publicznych, sposób prezentowania dzieł sztuki oparty na naukowych wytycznych historii sztuki stawał się bardziej powszechny (nowa galeria berlińska). Rodząca się dyscyplina obejmowała zarówno szeroko pojęte znawstwo sztuki - tzn. zdolność rozpoznawania dzieł, jak i umiejętność ich eksponowania oraz zabezpieczania. Wśród prac przekazujących tego rodzaju wiedzę na uwage zasługują: pierwszy podręcznik dla kolekcjonera - Considerazioni sulla pittura Guidona Manciniego ${ }^{13}$ czy Traitee de Museologie François Xaviera Burtina ${ }^{14}$ oraz późniejsza rozprawa autorstwa Johna Ruskina The Hanging of Pictures ${ }^{15}$. Ruskin przedstawia w swej pracy idee, które zrealizowano dopiero w latach 30. XX wieku, a mianowicie wieszanie obrazów tylko w jednym rzędzie, z wyraźnymi przerwami między jednym a drugim, by nie zakłócać kolorystycznego oddziaływania jednego dzieła na drugie. Postulował także, żeby w jednej sali umieszczać obrazy tylko jednego autora, aby uniknąć konfrontacji między twórcami.

Na powstały w XIX wieku przemysł ramiarski wpływ miał popyt, jaki nowa klientela narzucała rynkowi. W połowie tego stulecia w samej tylko Warszawie znajdowało się wiele prywatnych galerii, np. hrabiego Stanisława Kossakowskiego, szambelana Cypriana Lachnickiego, bankierów Leopolda Kronenberga i Jana Blocha ${ }^{16}$.

Oprawiano już nie tylko obrazy, ale także grafikę i fotografię. Na rynku sztuki obok starych ram pojawiały się masowo produkowane wersje stylowych ram historycznych oraz uproszczone wariacje stylowe, niskiej jakości artystycznej, a często i technicznej, gdyż tradycyjne materiały zastąpiono tanimi, co w dużym stopniu wpłynęło na ich jakość, gwarantując jednocześnie przystępną cenę. Reakcją na masowa produkcję było pod koniec XIX i na początku XX wieku projektowanie ram do obrazów przez ich twórców

\footnotetext{
12 Ibidem, s. 33-34.

13 1618-1621, Roma 1956-1957.

14 1808, Bruxelles 1808.

151857.

16 S. Jaroszewski, Kilka słów o Galerii Kossakowskich, [w:] Ars Auro Prior. Studia JOANNI Białostocki Sexagenario dicata, Warszawa 1981, s. 699.
} 
lub malowanie ich na biało (il. 5), co stanowiło przeciwwage dla złotych XIX-wiecznych ram eklektycznych czy alternatywę dla zniszczonych ram historycznych.

W latach 20. i 30. XX wieku dojrzała jednakże tendencja do wieszania obrazów w pojedynczych rzędach, choć nie tak, jak to postulował Ruskin na tłach koloru czerwonego czy zielonego, lecz białego, który zdaniem twórców zapewniał neutralność tła (il. 6).

Doprowadziło to do wieszania obrazów w sposób zupełnie nieadekwatny do wnętrz, które zajmowały. Odnosi się to m.in. do Luwru, Prado czy Kunsthistorisches Museum w Wiedniu. Zasada ta pokutuje w wielu galeriach do dnia dzisiejszego, choć coraz częściej wraca się do teorii Ruskina. Niezależnie od swojej surowości czy bogactwa, otoczenie zawsze wpływa na umieszczone w nim dzieło sztuki ${ }^{17}$.

W czasach socjalizmu wstydzono się wieszać obrazy w złoconych ramach, kojarzonych przecież z wyższą warstwą społeczną, potępianą przez społeczeństwo robotnicze. Doprowadzało to czasami do oprawiania obrazów w tandetne ramy, czasem nawet w proste niepolichromowane listwy.

Dziś jednak mniejsze znaczenie ma wnętrze, w którym wiszą obrazy, ledwie je zauważamy. Zwiedzający oglądają obrazy, które - umieszczone na odpowiednim tle i w odpowiednim dla nich obramieniu - zmuszają do kontemplacji układu obraz-rama-ściana i wynikających z tego wzajemnych relacji.

Dawniej często nabywano obrazy bez ramy, ta pojawiała się później wraz z całą dekoracją wnętrza, w którym się znajdowały. Dziś ramy zastąpiły antyramy, których zadania zostały zredukowane tylko do funkcji chroniącej obraz. Trudno w tym przypadku mówić o ozdabianiu przez nie wnętrza. Alternatywą są także współczesne reprodukcje ram historycznych, eklektyczne kompozycje fabryczne i warsztatowe.

Czy dziś ramy kształtują wnętrze? Nowe style aranżacji wnętrz wykorzystują stare i nowe wcielenia ram do obrazów.

17 A. Rotermund, op. cit., s. 36. 


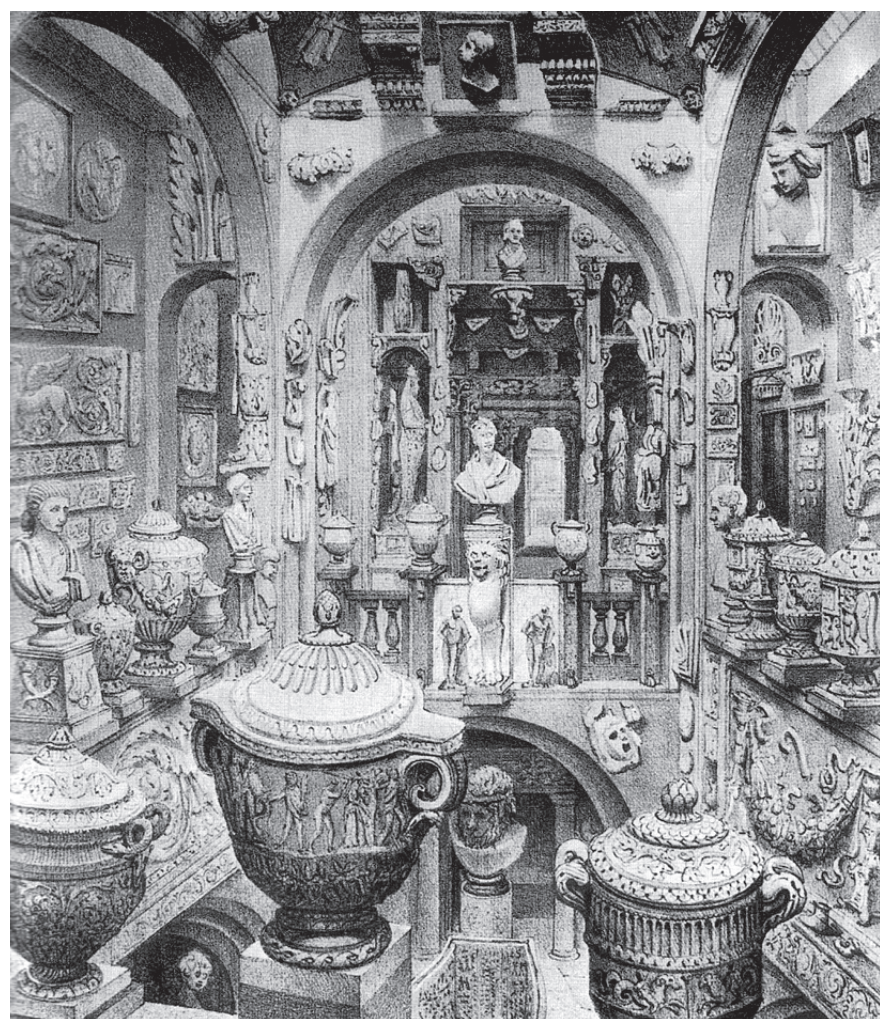

Il. 1. J. Soane, Galeria Pokój Belzoni 13, Lincolns Inn Fields z rezydencji Sir Johna Soane, 1835 r., za: M. Praz, An Illustrated History of Interior Decoration, Thames and Huston 1994, s. 241

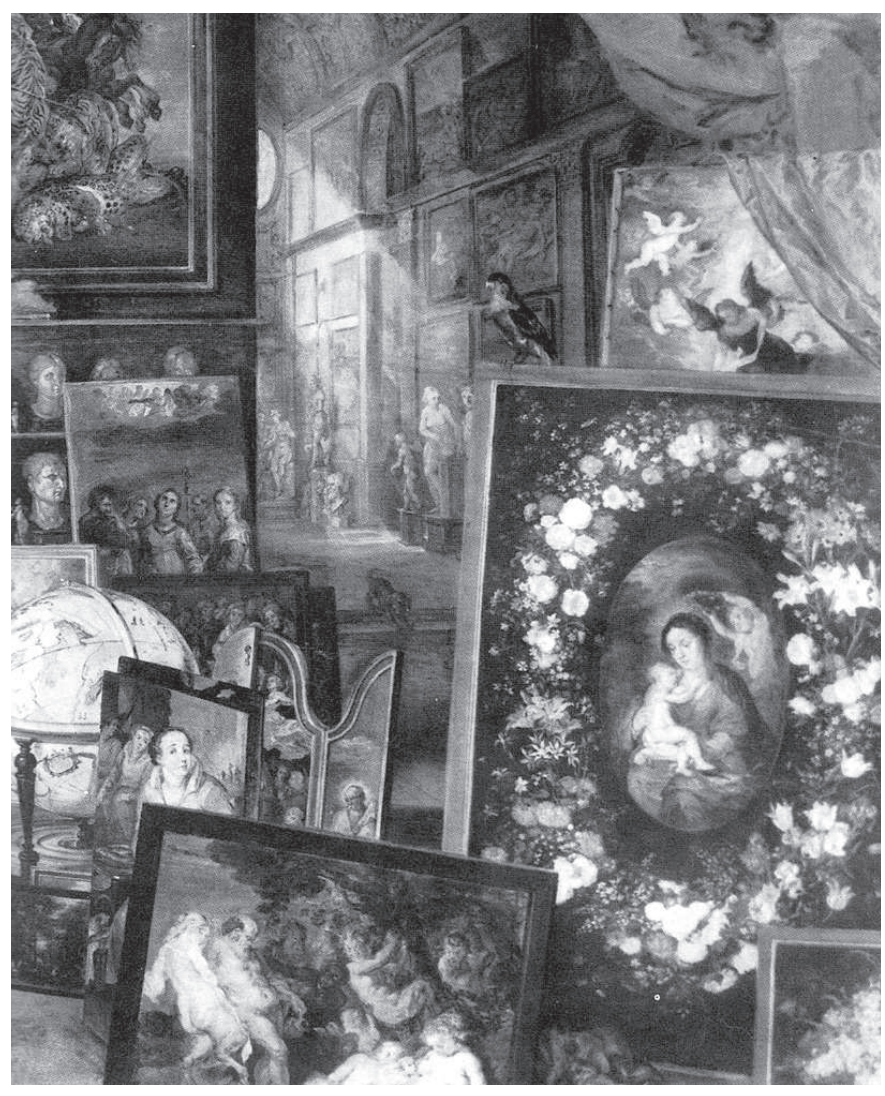

I1. 2. Bruegel Starszy, Alegoria zmystu wzroku, fragment, Prado, Madryt, za: M. Praz, op. cit., s. 134 


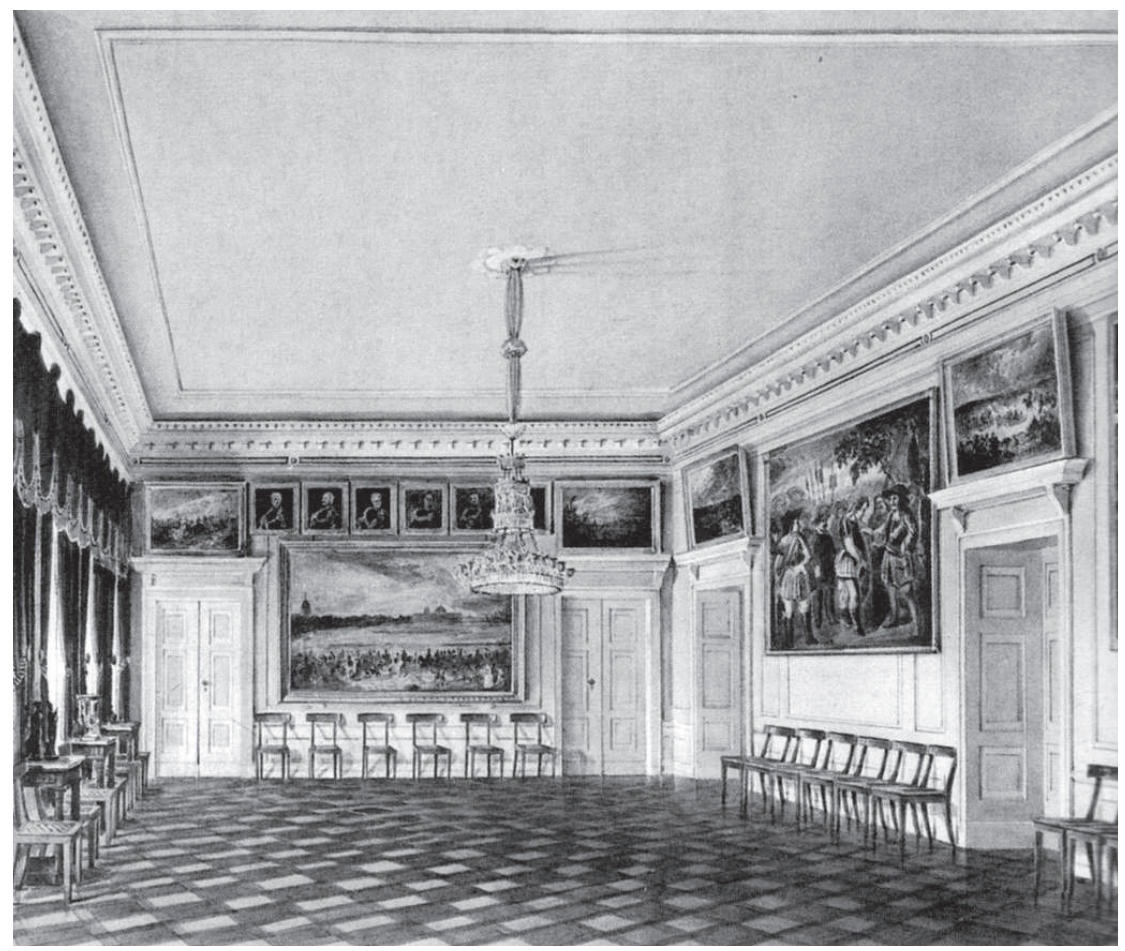

Il. 3. F. W. Klose, Jadalnia w pałacu Friedricha Wilhelma III $w$ Berlinie, Pałac Charlottenburg, Berlin, za: M. Praz, op. cit., s. 254

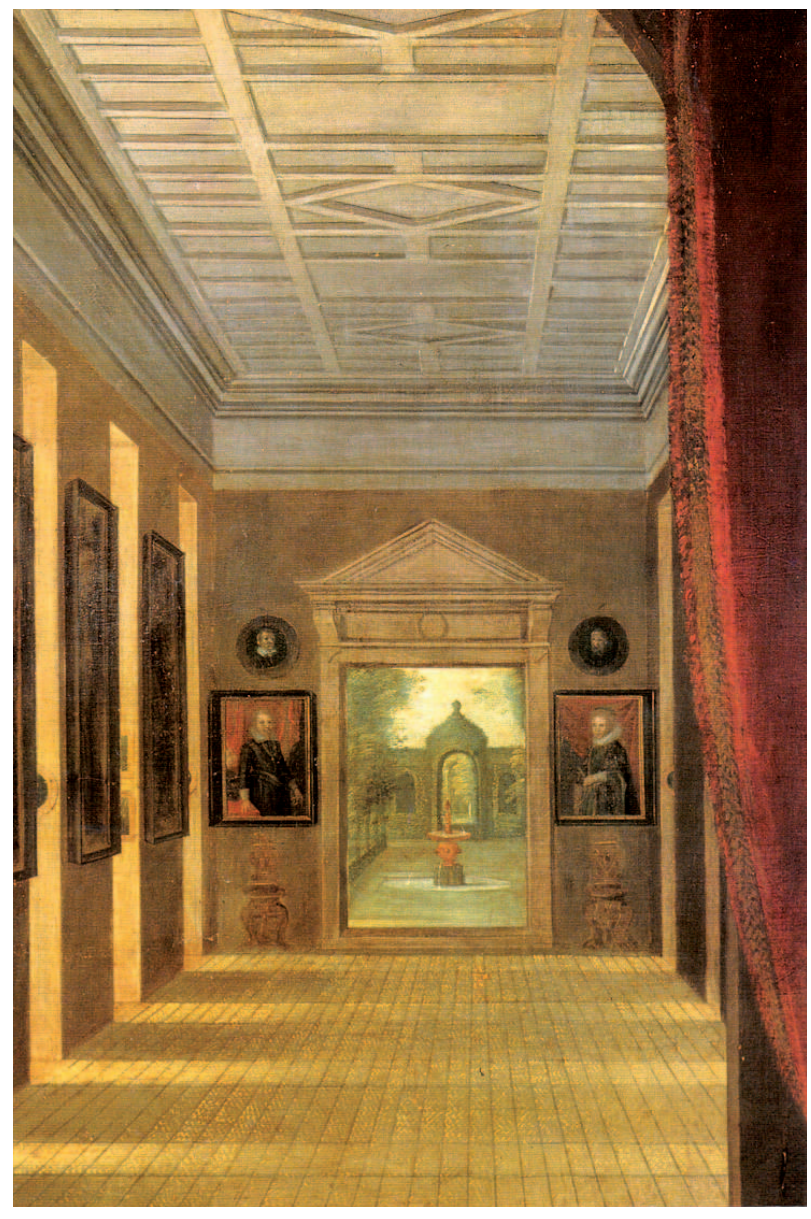

Il. 4. D. Mytens, A. Talbot, Countess of Arundel, fragment, Arundel Castle, depozyt National Portrait Gallery, Londyn, za: J. Simon, The Art of the Picture Frames, Artists, patrons and the Framing of Portraits in Britain, National Portrait Gallery, London 1996, s. 12 


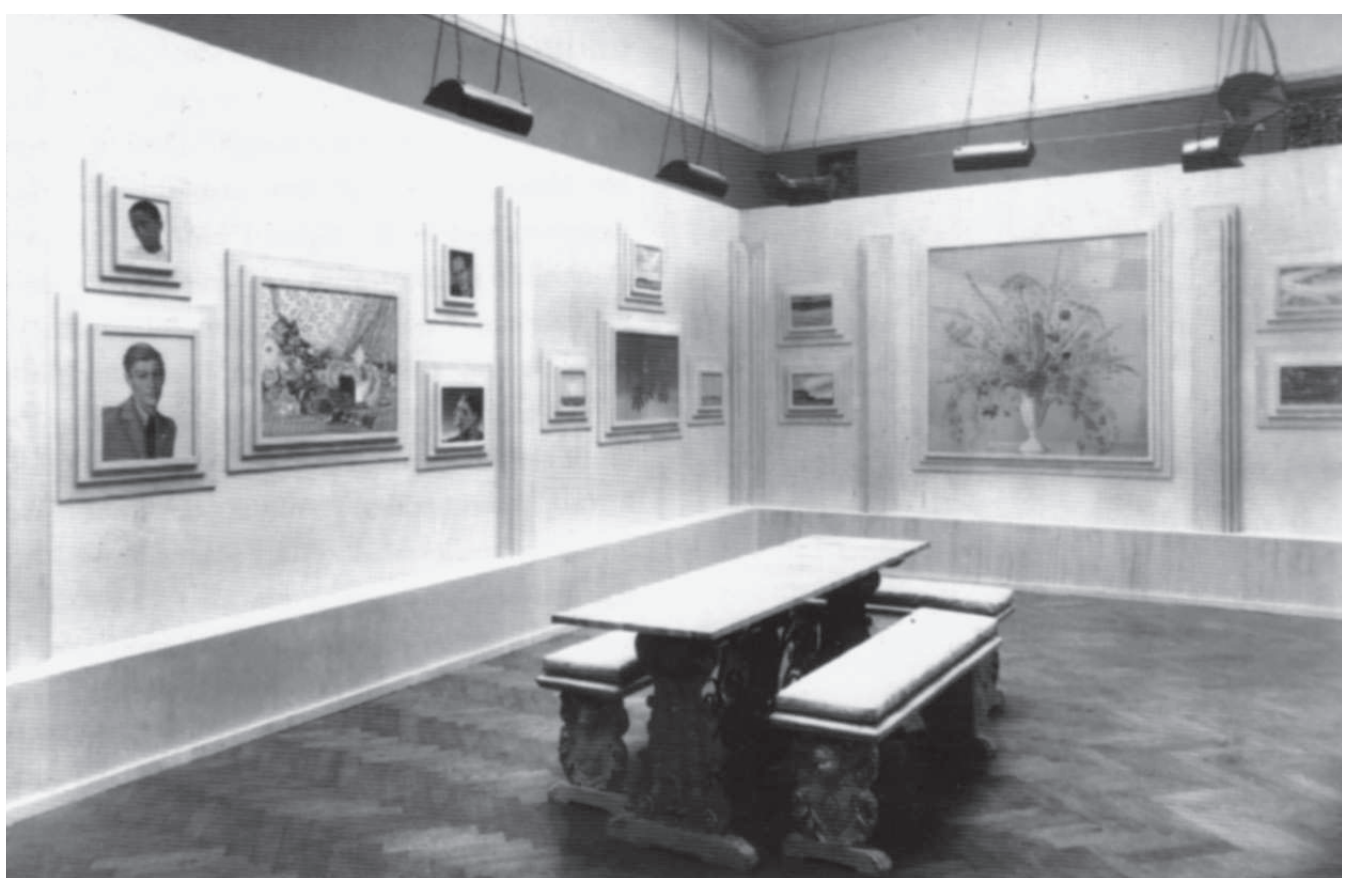

Il 5. Pokój Glucka zaprojektowany przez artystę na wystawę Fine Art Society w 1932 r., za: J. Simon, op. cit., s. 22

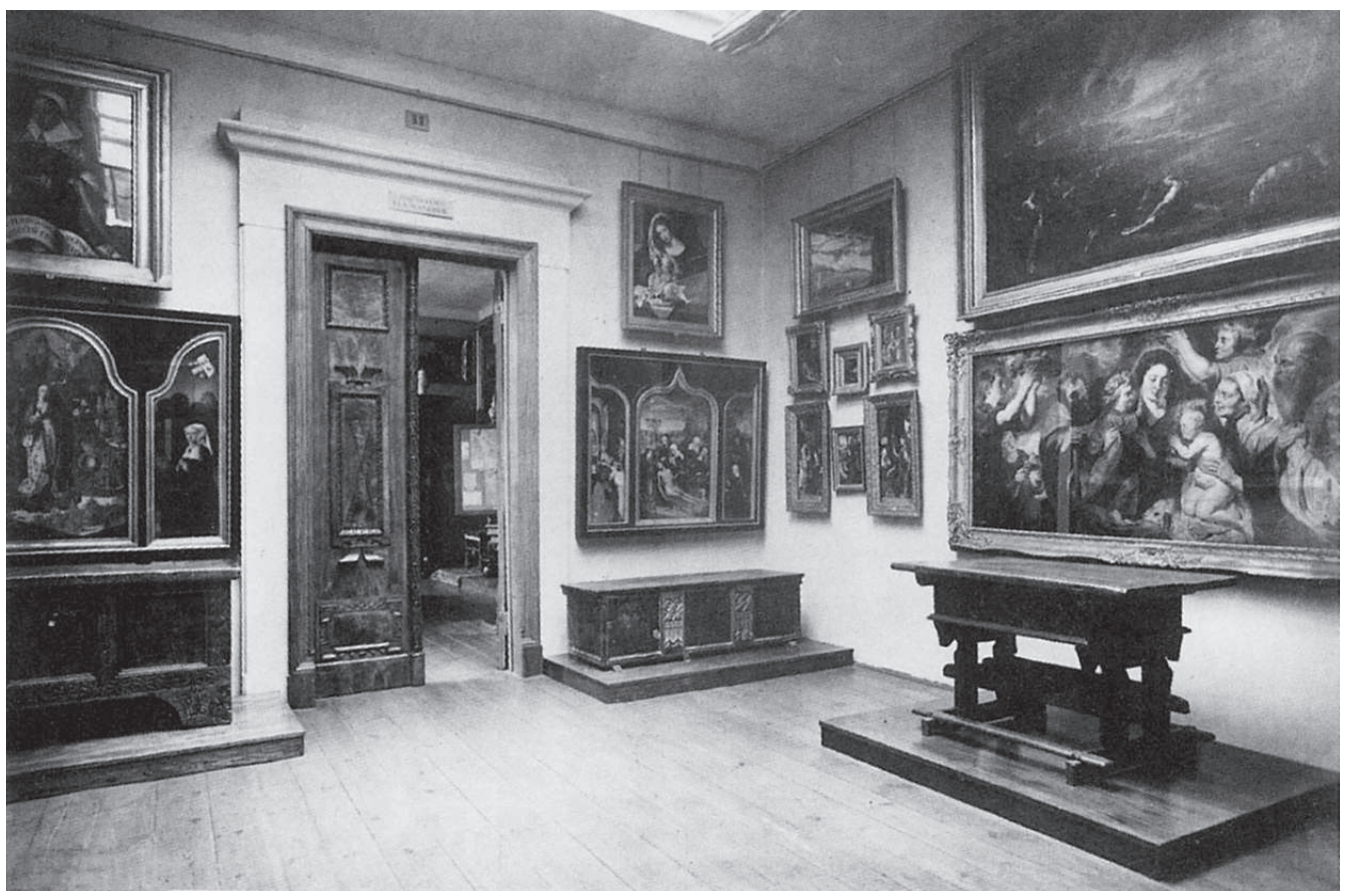

Il. 6. Sala z malarstwem flamandzkim w gmachu Muzeum Narodowego w Warszawie przy ul. Podwale 15, fot. 1927 r., za: Muzeum Narodowe $w$ Warszawie. Przewodnik, pod red. K. Murawskiej-Mathesius, D. Folgi-Januszewskiej, Warszawa 1998, s. 16 


\section{Summary}

\section{Picture frame in service interior design}

Picture frame, as others elements of interior design in various époques played more or less auxiliary role towards such elements as the architecture or furniture. So not only the theme was important, but also the surrounding, in which the painting was set. 